\section{Development of a New Maize (Zea mays L.) Breeding Program}

\author{
Pál Pepó - Szilárd Tóth \\ University of Debrecen, Centre of Agricultural Sciences, \\ Faculty of Agricultural Sciences, \\ Department of Genetics and Plant Breeding, Debrecen
}

\section{SUMMARY}

Genetic manipulation may not replace any conventional method in crop breeding programs, but it can be an important adjunct to them. Plant regeneration via tissue culture is becoming increasingly more common in monocots such as corn (Zea mays L.). In vitro culturability and regeneration ability of corn decreased as homozigosity increased, which suggested that these two attributes were controlled primarily by dominant gene action. Pollen (gametophytic) selection for resistance to aflatoxin in corn can greatly facilitate recurrent selection and screening of germplasm for resistance at a much less cost and shorter time than field testing. Integration of in vivo and in vitro techniques in maize breeding program has been developed to obtain desirable agronomic attributes, speed up the breeding process and enhance the genes responsible for them. The efficiency of anther and tissue cultures in most cereals such as maize and wheat have reached the stage where it can be used in breeding programs to some extent and many new cultivars produced by genetic manipulation have now reached the market.

\section{INTRODUCTION}

In the past, conventional breeding methods have been quite successful in improving crop yields throughout the world. Genetic improvements have been estimated to account for about $50 \%$ of the total realised gains in yield per unit area of major crops over the past fifty years. Rates of gain attributable to genetic improvement have generally been linear and show no sign of slackening. The role of breeding methodology to improve cereals for grain yield, disease resistance and other agronomic traits is significant. Conventional breeding methods, however are laborious and time and space consuming. Successful employment of anther or pollen culture could accomplish development of plants with 100\% homozygozity in much shorter time, thus making the breeding process more efficient in use of critical resources.

Whereas, in vitro methods, such as anther or tissue culture may not replace a conventional breeding program, they can be an important adjunct to it. The discovery of viable haploid plants and doubling of their chromosomes mean that homozygous plants could be obtained in one generation. Nevertheless, haploidization techniques applied to many species appeared only during the mid-sixties with the in vitro culture of pollen grains inside the anthers. The double haploids may allow: I./ production of strictly homozygous lines with a progeny as homogenous as possible. II./ considerable saving in time for homozygous line development.
III./ direct choice of individuals for genetic characters.

The other possible option for increasing variability is to establish regenerable cell cultures and to improve to economically important traits of cereals. Although all plant cells are derived from fertilized egg cell and contain identical information, callus derived from somatic cells varies in its competence to express totipotency. Cell and tissue culture per se generates genetic variation detected in the progeny of regenerated plants (somaclonal variation). Success in the selection of mutants resistant to pathotoxins, aminoacids and their analogous, and herbicides/insecticides demonstrates the usefulness of tissue culture selection of biochemical mutants for crop improvement.

\section{LITERATURE}

Hungarian maize production utilises many foreign hybrids that are derived from only a few inbred lines. Because of this genetic vulnerability production can be in a serious danger and quick gene erosion is a possibility. During the past ten years maize production level has remained unchanged and the opportunity of further development would be to develop new inbreeds with desirable agronomic attributes.

The regeneration of plants from tissue cultures of corn (Zea mays L.) was first reported by Green and Phillips (1975) utilising immature embryos as the tissue source. Using the same tissue system. Spinger et al. (1979) demonstrated that the plant regeneration was by means of organogenesis.

Rice et al. (1978) found that pliant regeneration could also occur by somatic embryogenesis. Regeneration of maize via somatic embryogenesis has now been reported by several investigators (Green, 1982; Armstrong and Green, 1982; Vasil and Vasil, 1986; Novak et al., 1983, Hodges et al., 1986). Regeneration of monocotyledonous plants (e.g. maize) via somatic embryogenesis from primary callus is poorly understood and progress in this area has been very slow (Tomes, 1985).

Both types of regeneration arise from hard, white or yellow callus that appears distantly different from the granular, gray-yellow and translucent callus incapable of plant regeneration. Consequently, visual selection of plant regeneration-competent calli has become the method of choice for detecting and maintaining plant regeneration capability in Zea mays L. tissue cultures (Springer et al., 1979; Torne et al., 1980; Armstrong and Green, 1982; Green, 
1982; Lu et al., 1982, 1983; Rhodes et al., 1982; Sachs et al., 1982).

Plant regeneration from maize tissue culture has mainly been obtained from callus derived from immature embryo (Green and Philips, 1975; Duncan et al., 1985). Successful plant regeneration has also been reported from calli initiated from anthers (Ting et al., 1981), glumes (Suprassana et al., 1986), immature tassels (Rhodes et al., 1982), leaf bases (Chang, 1983), mesocotyls (Harm et al., 1976), seedling segments (Santos et al., 1984), mature embryos (Wang, 1987). Immature embryo-derived callus is more embryogenic and efficient for plant regeneration than calli from other explant tissues.

All the plant tissues used to date must be obtained from living plants which require time and space to grow. In maize the ability of leaf cell to express morphogenic capability decreases as the leaf matures. Chang (1983) presented a study about regeneration ability of leaf tissue derived from maize seedlings grown from immature embryos in vitro. A method for the induction of embryogenic and organogenic calli from maize mature embryos reported by Wang (1987) could satisfy the time and space requirements.

The possible genetic mechanism for controlling plant regeneration were studied for corn (Hodges et al., 1985, 1986; Tomes, 1985). It was concluded that regeneration from immature embryo-derived calli was controlled by a few nuclear genes or a few gene clusters. A large proportion of genotypes variation for formation of type 1 and type 2 callus in maize was die to additive gene effects white heterosis positively increased culture response (Tomes and Smith, 1985). A significant maternal effect was also noted for B 73, but not for Lancester type lines. Callus growth from mature embryos on a modified LD medium was also controlled mainly by additive gene effects (general combining ability) (Nesticky et al., 1983). Willman et al. (1989) found the additive gene effects to be more important than the dominant gene effects for the percent of somatic embryogenesis and percent of number of plants regenerated per embryo when generation means were analysed. Cytoplasmic, maternal and/or paternal effects were significant for frequency of somatic embryos as well as frequency or number of plants regenerated per embryo. Analysis of genetic variances suggested that at least gene or block of genes control led the expression of the frequency of somatic embryogenesis.

Regeneration of maize from cell and tissue cultures has been limited to few specific genotypes and media combinations (Green and Philips, 1975; Hodges et al., 1985, 1986; Kamo et al., 1985; Tomes, 1985). Media improvements boost the general mean of the entries tested but genotypic differences remained (Duncan et al., 1985). Studies on the genotype component can be used to predict probabilities for a desired response level and to describe in more detail the nature of the tissue culture response (Tomes, 1985; Tomes et al., 1985).
Mycotoxins, in general, reportedly contaminate about one-quarter of the world's yearly food and feed crops. Effects of mycotoxin consumption on animal health range from decreased growth rates and reproductive efficiency to mortality. In addition, there is an increasing concern about the effects of aflatoxin on human health, as aflatoxins have been linked to liver cancer. The occurrence of aflatoxin in food is viewed as a potential threat to the food supply. It has been deemed necessary to develop efficient methods that will prevent aflatoxin contamination in crops. Host-plant resistance is the mot logical and useful method of control (Gorman and Kang, 1991).

Since the early 1970s, corn breeder and pathologists have made a concentrated effort to eliminate or reduce aflatoxin contamination in corn. To develop proper breeding strategies for incorporating resistance to a disease into germplasm, a breeder needs to (i) identify and/or develop sources of resistance, and (ii) determine the genetic nature of resistance. (Gorman and Kang, 1991). Investigations have been conducted to identify sources of resistance (Scott and Zummo, 1988; Kang et al., 1990). Identification of aflatoxin-resistant genotypes has been difficult due to the erratic nature of infection by Aspergillus (Gorman and Kang, 1991). Natural infection has not been reliable enough to screen for resistance. Attempts have been made to identify effective artificial inoculation techniques. (Zummo and Scott, 1985; Zummo and Scott, 1989; Scott et al., 1991). An efficient inoculation technique is required for improving populations for resistance to the Aspergillus group of fungi or aflatoxin via recurrent selection procedures. Success from recurrent selection for improving resistance to the fungus or aflatoxin has not been reported. One of the reasons might be non availability of a suitable inoculation technique for that purpose. In addition, thus far, screening has only been conducted at the sporophytic (plant or seed) level.

Thus far, only a few studies on inheritance of resistance have been conducted (Zuber et al., 1978; Widstrom et al., 1984; Gardner et al., 1987; Darrah et al., 1987; Gorman et al., 1991). Progress in elucidating genetic mechanisms and identifying sources of resistance to aflatoxin has been slow primarily because genotype evaluation in the field (sporophytic selection) is laborious, expensive, and time consuming. Selection at the pollen level (male gametophytic selection) for screening for resistance to aflatoxin did not receive much attention until recently. The gamatophytic generation has appropriately been called 'the forgotten generation'.

A total of $60-70 \%$ of structural genes controlling traits of the sporophytic generation (plant) are expressed in the gametophytic generation (pollen). (Mulcahy, 1971; Mulcahy and Mulcahy, 1987; Ottaviano et al., 1980; Tanksley et al., 1981; Smith, 1986). This genetic overlap between the sporophytic and gametophytic generations offers a tremendous potential for modifying the sporophyte by applying selection pressure on the gametophyte. A corn plant 
produces 2 to 5 million pollen grain that can be subjected to selection. Selection pressure applied to pollen produced by a genetically homogeneous, heterozygous plant is expected to produce genetic changes in the sporophytic population (Ottaviano and Mulcahy, 1989).

Pfahler (1985, 1983) indicated that if a significant part of the physiological processes controlling pollen development, pollen germination, and pollen tube elongation were under the control of the haploid gametophytic genome, it would be expected that the genetic variability expressed in the pollen population of a single heterozygous plant would lead to important selection effects due to pollen competition. This expectation was based on the assumption that not only the genetic variability expressed by the male gametophytic population is of haploid origin, but also that several $(60-70 \%$ of the total) genes expressed in the gametophytic phase are equally expressed in the sporophyte (,haplo-diploid” gene expression or gametophytic-sporophytic genetic overlap).

\section{MATERIALS AND METHODS}

Two maize populations developed in the LSU maize breeding program, víz., ((Mo17 x B73) $\mathrm{x}$ Yellow Creole)) and (Mo17 x B 73) x (L331 x Yellow Creole), hereafter refered to as L91 R population and L331 population, respectively, were evaluated for their in vitro culturability and regeneration potential. The So, S1, S2 generations were subjected to tissues culture using the following procedures: seeds were surface-sterilised for $10 \mathrm{~min}$. in a $0.2 \%$ aqueonus mercurous chloride solution, rinsed overnight under running tap water and re- sterilised for 5 min. in a $0.2 \%$ aqueous mercurous chloride solution, followed by several water rinses. twenty five kernels of each generation were germinated. Aseptic seedlings we grown on a $1 \%$ aga-solidified medium cotaining the inorganic constituents of Murashige and Skoog (1962), 3\% sucrose, $26.7 \mu \mathrm{M}$ glycine, $4.1 \mu \mathrm{M}$ nicotinic acid, 2.4 $\mu \mathrm{M}$ pyridocine- $\mathrm{HCl}$ and $0.3 \mu \mathrm{M}$ thiamine- $\mathrm{HCl}$.

Radicles were aseptically separated from plumules at scutellar nodes and the explants were cut into five, 2-3 mm long pieces. These explants and intact, mature embryos were plated on MS medium. The $\mathrm{pH}$ was adjusted to 5.8 before autoclaving. Incubation was done at $26{ }^{\circ} \mathrm{C}$ with $16 / 8$ photoperiod.

The 2,4-D concentration varied between 1 and 5 $\mathrm{mg} / \mathrm{L}$. After callus induction, meristematic segments were discarded; the remainder were transferred to the above culture medium for callus proliferation to induce further differentiation, calli were subcultured on MS medium supplemented with different concentrations of 2,4-D and zeatin. Regenerated plantlets were transferred to hormone-free medium for root development.

\section{RESULTS AND DISCUSSION}

Results (Table 1.) indicated that the callus induction frequency for the two populations ranged from 4.7 to $60.9 \%$. The highest frequency of callus formation was exhibited by radicle tissue and the lowest by the embryo. In both populations, callus induction frequency decreased as amount of homozygosity increased, which suggested that callus induction was controlled primarily by dominant gene action.

Table 1: Callus initiation and regeneration for L331 and L91R populations

\begin{tabular}{|c|c|c|c|c|c|}
\hline \multirow[t]{2}{*}{ Explant } & \multirow[t]{2}{*}{ Inbred stage } & \multicolumn{2}{|c|}{ Callus induction } & \multicolumn{2}{|c|}{ Regeneration } \\
\hline & & L331 & L91R & L331 & L91R \\
\hline \multirow[t]{4}{*}{ Radicle ${ }^{\circledR}$} & \multirow{4}{*}{$\begin{array}{c}\mathrm{S}_{\mathrm{o}} \\
\mathrm{S}_{1} \\
\mathrm{~S}_{2} \\
\text { Mean }\end{array}$} & 60.9 & 41.1 & 4.75 & 1.51 \\
\hline & & 58.0 & 32.0 & 4.45 & 0.00 \\
\hline & & 56.0 & 23.9 & $\underline{0.00}$ & 0.00 \\
\hline & & 58.3 & 33.4 & 2.70 & 0.59 \\
\hline \multirow[t]{4}{*}{ Plumule (P) } & \multirow{4}{*}{$\begin{array}{c}\mathrm{S}_{\mathrm{o}} \\
\mathrm{S}_{1} \\
\mathrm{~S}_{2} \\
\text { Mean }\end{array}$} & 41.9 & 30.1 & 9.94 & 3.05 \\
\hline & & 39.0 & 23.9 & 6.65 & 1.26 \\
\hline & & 38.9 & 19.0 & $\underline{4.43}$ & $\underline{0.00}$ \\
\hline & & 40.0 & 25.1 & 6.95 & 1.65 \\
\hline \multirow[t]{4}{*}{ Embryo (E) } & \multirow{4}{*}{$\begin{array}{c}\mathrm{S}_{\mathrm{o}} \\
\mathrm{S}_{1} \\
\mathrm{~S}_{2} \\
\text { Mean }\end{array}$} & 40.0 & 9.8 & 5.00 & 2.17 \\
\hline & & 38.2 & 7.2 & 2.06 & 1.20 \\
\hline & & 35.8 & 4.7 & 1.05 & 0.00 \\
\hline & & 38.0 & 7.5 & 2.75 & 1.25 \\
\hline \multirow[t]{6}{*}{ Mean: R+P+E } & \multirow[t]{2}{*}{$\mathrm{S}_{\mathrm{o}}$} & 50.9 & 33.3 & 7.03 & 2.26 \\
\hline & & $(601 / 1181)$ & $(228 / 1016)$ & $(83 / 1181)$ & $(23 / 1016)$ \\
\hline & \multirow[t]{2}{*}{$\mathrm{S}_{1}$} & 47.9 & 26.1 & 4.79 & 0.67 \\
\hline & & $(590 / 1232)$ & $(233 / 893)$ & $(59 / 1232)$ & $(6 / 893)$ \\
\hline & \multirow[t]{2}{*}{$\mathrm{S}_{2}$} & 46.9 & 19.9 & 3.92 & 0.00 \\
\hline & & $(577 / 1230)$ & $(134 / 673)$ & $(25 / 1230)$ & $(0 / 673)$ \\
\hline
\end{tabular}

Explants differed in plant regeneration percentages in both populations. A maximum number of plants was regenerated from plumule in the L331 population. No plant regeneration was 
noted in the S2 generation of L91R population. Results suggested that plant regeneration would be increasingly more difficult in the inbred generations and that prior to embarking on a tissue culture-based breeding program, responsive genotypes must be identified for use in a breeding program.

Microscopic investigations were carried out to investigate the effect of Aspergillus flavus spores and aflatoxin B1 on in vitro pollen germination and demonstrated that Aspergillus spp. spores and aflatoxin B1 inhibited pollen germination (Table 2).

Table 2: Mean percent germination of pollen grains from the $\mathbf{F}_{2}$ of the single cross

(Mp 313 E x SC 212 M)

\begin{tabular}{|l|r|}
\hline \multicolumn{1}{|c|}{ Treatment } & \multicolumn{1}{c|}{$\begin{array}{c}\text { Mean pollen grain } \\
\text { germination (\%) }\end{array}$} \\
\hline Control & $71,5 \mathrm{a}^{*}$ \\
\hline Aspergillus parasiticus spores & $44,2 \mathrm{~b}$ \\
\hline Aflatoxin B1 (400 ppm) & $42,4 \mathrm{~b}$ \\
\hline Aspergillus flavus spores & $23,7 \mathrm{c}$ \\
\hline
\end{tabular}

- Means followed by the same letter are not significantly different at the 5\% level of probability according to Duncan's New Multiple Range Test.

Resistance to aflatoxin is quantitative in nature (Gorman and Kang, 1991). In sporophytic selection involving a quantitative trait, controlled by genes $4^{\mathrm{n}}$ $\mathrm{F}_{2}$ plants are required to recover all allelic combinations. This means that if a trait is controlled by 15 genes, over one billion $F_{2}$ plants or seed would need to be evaluated, which would be almost impossible in field studies. On the contrary, millions of pollen grains can easily be evaluated in petri dishes.

Gametophytic selection could greatly facilitate recurrent selection and screening of germplasm for developing resistance to aflatoxin and it could also be used in identifying with ease resistant inbred lines, hybrids, and segregating populations.

Another benefit of this pollen screening technique could be that costly aflatoxin assays of field-grown corn would be unnecessary and a considerable larger amount of germplasm could be screened throughout the year (plants could be grown in the field in summer and in the greenhouse in winter to supply needed pollen) at a much lower cost and in a shorter time. field screening, which is the current practice, can only be done in the summer.

The broad variety of diploid and double haploid lines produced in vitro are increasingly used in practical breeding programs (Figure 1.). We have employed anther culture and tissue culture techniques to develop lines with resistance to aflatoxins and herbicides, and other desirable agronomic traits such as fast dry-down rate, better stalk and seed quality, and weevil resistance. As figure shows we used a complex maize breeding program that was developed to obtain desirable agronomic attributes and speed up the breeding process and enhance the genes responsible for them. Depending on the nature of the source material, e.g., synthetics. $F_{1}$, open-pollinated varieties, as well as the breeding aims, one or more haploid (pollen) or diploid (tissue) steps have been made and the $F_{1}$ hybrids or selfed progenies in later generations have served as source material for haploidization or tissue cultures. One haploid step followed by selection in the greenhouse/field or diploid step after selection on a cell/plant level during the first androgenetic $\left(\mathrm{A}_{1}\right)$ or diploid progenies $\left(D_{1}\right)$ and two subsequent selfed generations $\left(A_{2}, A_{3}, D_{2}, D_{3}\right)$ proved to be the most efficient procedure, if characters from related varieties were to be combined. To make this genetic manipulation system more efficient, we have combined it with several backcrosses. 


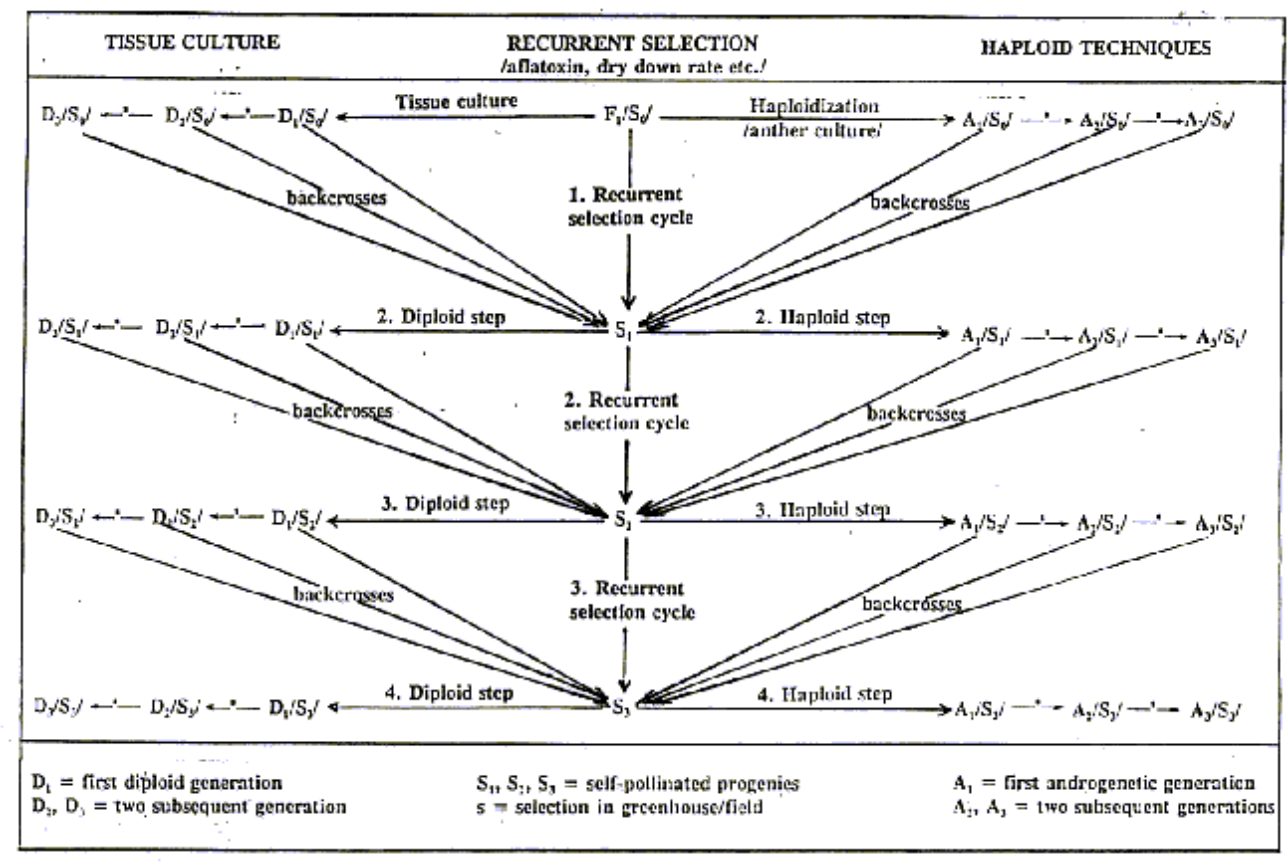

\section{CONCLUSION}

Combination of conventional and new genetic recombination methods (in vivo and in vitro genetic manipulation) max result in such cereal varieties and hybrids as could meet production demands better. The efficiency of anther and tissue cultures in most cereals such as maize have reached the stage where it can be used in breeding programs to some extent and many new cultivars produced by this system have now reached the market.

\section{REFERENCES}

Armstrong, C. L.-Green, C. E. (1982): Initiation of friable, embryogenic maize callus: the role of L-proline In: Agron. Abstr. 74 ${ }^{\text {th }}$ Ann. Meet., 89. American Society of Agronomy

Chang, Y. F. (1983): Plant regeneration in vitro from leaf tissues derived from cultured immature embryos of Zea mays. Plant Cell Reports 2. 183-185.

Darrah, L. L.-E. B. Lillehoj-M. S. Zuber-G. E. Scott-D. Thompson-D. R. West-N. W. Widstrom-B. A. Fortnum (1987): Inheritance of aflatoxin B1 levels in maize kernels under modified natural inoculation with Aspergillus flavus. Crop Sci. 27. 869-872.

Duncan, D. R.-E. M. Williams-B. E. Zehr-J. M. Widholm (1985): The production of callus capable of plant regeneration from immature embryos of numerous Zea mays genotypes. Planta 165. 322-332.

Gardner, C. A. C.-L. L. Darrah-M. S. Zuber-J. R. Wallin (1987): Genetic control of aflatoxin production in maize. Plant Dis. 71. 426-429.

Gorman, D. P.-M. S. Kang (1991): Preharvest aflatoxin contamination in maize: Resistance and genetics. Plant Breeding 107. 1-10.

Gorman, D. P.-M. S. Kang-T. E. Clevelend-R. L. Hutchinon (1991): General and specific combining ability for resistance to field aflatoxin accumulation on maize grain. Am. Soc. Agron. Abstr. 95.
Green, C. E. (1982): Somatic embryogenesis and plant regeneration from the friable callus of Zea mays. In: Plant tissue culture 1982. (Proc. V. Int. Congr. Plant Tissue and Cell Culture) 107-08.

Green, C. E.-R. L. Philips (1975): Plant regeneration from tissue culture of maize. Crop. Sci. 15. 417-421.

Harm, C. T.-H. Lorz-I. Potrykus (1976): Regeneration of plantlets from callus culture of Zea mays L. z. Pflanzenzücht. 77. 347351.

Hodges, T. K.-K. K. Kamo-R. M. Becwar-S. Schroll (1985): Regeneration of maize. In: Zaitlin, M.: Day, P., Hollaender. A. eds. Biotechnology in Plant Science: Relevance to Agriculture in the Nineteen Eighties. Orlando, Florida: Academic Press: 15-33.

Hodges, T. K.-K. K. Kamo-W. C. Imbrie-M. R. Becwar (1986): Genotype specifity of somatic embryogenesis and regeneration in maize. Biotechnology 3. 218-223.

Kamo, K. K.-M. R. Becwar-T. K. Hodges (1985): Regeneration of Zea mays L. from embryogenic callus. Bot Gaz. 146. 327-334.

Kang, M. S.-E. B. Lillehoj-N. W. Widtrom (1990): Field aflatoxin contamination of maize genotypes of broad genetic base. Euphytica 51. 19-23.

Lu, C.-K. I. Vasil-Ozias, P.-Akins (1982): Somatic embryogenezis in Zea mays L. Theor. Appl. Genet. 62. 109-112. 
Mulcahy, D. L. (1971): Correlation between gametophytic and sporophytic characteristics in Zea mays L. Science 171. 11551156.

Mulcahy, D. L.-G. B. Mulcahy (1987): The effects of pollen competition. Am. Scientist 75. 44-50.

Nesticky, M.-F. J. Novak-A. Piovarci-M. Dolezelova (1983): Genetic analysis of callus growth of maize (Zea mays L.) in vitro. Pflanzenzüchtung 91. 322-328.

Novak, F. J.-M. Dolezelova-M. Nesticky-A. Piavarci (1983): Somatic embryogenesis and plant regeneration in Zea mays $\mathrm{L}$. Mayidica, XXVIII. 381-390.

Ottaviano, E.-D. L. Mulcahy (1989): Genetics of angiosperm pollen. In J. G. Scandalios (ed) Advances in genetics, 1-64. Academic Pres, Inc., CA.

Ottaviano, E.-M. Sari-Gorla-D. L. Mulcahy (1980): Pollen tube growth rates in Zea mays: Implications for genetic improvement of crops. Science 210. 437-438.

Pfahler, P. L. (1983): Comparative effectiveness of pollen genotype selection in higher plants. In: D. L. Mulcahy-E. Ottaviano (eds.) Pollen: Biology and implications for plant breeding. Elsevier Biomedical, New York, Amsterdam Oxford. 366-367.

Pfahler, P. L. (1985): Factors affecting male transmission in maize (Zea mays L.). In: D. L. Mulcahy (ed.) Gamete competition in plants and animals. North Holland, Amsterdam, 115-124.

Rhodes, C. A.-E. C. Green-L. R. Phillips (1982): Regenerable maize tissue cultures derived from immature tassels. Maize Genet. Coop. Newslett. 56. 148-149.

Rice, T. B.-R. K. Reid-P. N. Gordon (1978): Morphogenesis in field crops. In: Propagation of higher plants through tissue culture. 262-277. Hughes, K. W.-Henke, R.-Constantin, M. eds. National Technical Information Service, U. S. Department of Commerce, Springfield, Va., USA.

Sachs, M. M.-H. Lorz-E. S. Dennis-A. Elizur-R. J. Ferl-L. W. Gerlach-A. J. Pryor-W. J. Peacock (1982): Molecular genetic analysis of the maize anaerobic response. In: Maize for biological research, 139-144, Sheridan, W., ed. Plant Molecular Biology Association, Charlotteswille, Va., USA.

Santos, M. A.-M. J. Torne-J. L. Blanco (1984): Methods of obtaining maize totipotent tissues. Tissue and Organ Culture, 145-152.

Scott, G. E.-N. Zummo (1988): Sources of resistance in corn to kernel infection by Aspergillus flavus in the field. Crop Sci. 28. 504-507.

Scott, G. E.-N. Zummo-E. B. Lillehoj-N. W. Widstrom-M. S. Kang-D. R. West-G. A. Payne-T. E. Clevaland-O. H. CalvertB. A. Fortnum (1991): Aflatoxin in corn hybrids field inoculated with Aspergillus flavus. Agron. J. 83. 5955-598.

Smith, G. A. (1986): Sporophytic screening and gametophytic verification of phytotoxin tolerance in sugarbeet (Beta vulgaris L.). In D. L. Mulcahy-G. B. Mulcahy-E. Ottaviano (eds.) Biotechnology and ecology of pollen 83-88. SprigerVerlag, New York.

Springer, W. D.-E. C. Green-A. K. Kohn (1979): A histological examination of tissue culture initiation from immature embryos of maize. Protoplasma 101. 269-281.

Supressena, P.-K. V. Rao-G. M. Reddy (1986): Plantlet regeneration from glume calli of maize (Zea mays L.) Theor Appl. Genet. 72. 120-122.

Tanksley, S. D.-D. Zamir-C. M. Rick (1981): Evidence for extensive overlap of sporophytic and gametophytic gene expression in Lycopersicon esculentum. Science 213. 453455.
Ting, Y. C.-M. Yu-W. Z. Zheng (1981): Improved anther culture maize (Zea mays) Plant Sci. Lett. 23. 139-145.

Tomes, D. T. (1985): Cell culture, somatic embryogenesis and plant regeneration in maize, rice, sorghum and millets. In: Bright, S. W. J.-Jones, M. G. K., eds. Cereal Tissue and Cell Culture. Hingham, MA: Martinus /Nijnoff/W. Junk; 175-203.

Tomes, D. T.-O. S. Smith (1985): The effect of parental genotype on initiation of embryogenic callus from elite maize (Zea mays L.) germplasm. Theor. Appl. Gen. 50. 505-509.

Torne, J. M.-A. M. Santos-A. Pons-M. Blanco (1980): Regeneration of plants from mesecotyl tissue cultures of immature embryos of Zea mays L. Plant Sci. Lett. 17. 339344.

Vasil, V.-K. Vasil (1986): Plant regeneration friable embryogenic callus and cell suspension culture Zea mays L. and J. Plant 
Physiel. 124. 399-408.

Wang, A. S. (1987): Callus induction and plant regeneration from maize mature embryos. Plant Cell Reports. 6. 360-362.

Widstrom, N. W.-D. M. Wilson-W. W. McMillian (1984): Ear resistance of maize inbreds to field aflatoxin contamination. Crop Sci. 24. 1155-1157.

Willman, M. R.-S. M. Schroll-T. K. Hodges (1989): Inheritance of somatic embryogenesis and plantlet regeneration from primary (type 1) callus in maize. In vitro cell. and Dec. Biol. 25. 95100.

Zuber, M. S.-O. H. Calvert-W. F. Kwolek-E. B. Lillehoj-M. S. Kang (1978): Aflatoxin B1 production in an eight-line diallel of Zea mays infected with Aspergillus flavus. Bhytopathology 68. 1345-1349.

Zummo, N.-G. E. Scott (1985): Evaluation of field inoculation techniques for screening corn genotypes against kernel infection by Aspergillus flavus in Mississippi. Phytopathology 75. 1330.

Zummo, N.-G. E. Scott (1989): Evaluation of field inoculation techniques for screening maize genotypes against kernel infection by Aspergillus flavus in Mississippi. Plant Dis. 73. 313-316. 